\title{
KSIĄDZ PROFESOR BOLESŁAW KUMOR. HISTORYK KOŚCIOLA I DYDAKTYK. SESJA NAUKOWA W 15. ROCZNICĘ ŚMIERCI. LUBLIN 21 IX 2017
}

W dniu 21 września 2017 r. odbyła się ogólnopolska konferencja naukowa zorganizowana przez Ośrodek Archiwów, Bibliotek i Muzeów Kościelnych KUL, poświęcona pamięci ks. prof. Bolesława Kumora (Ksiądz Bolesław Kumor. Historyk kościoła i dydaktyk. W 15. rocznice śmierci).

Konferencja została zainaugurowana mszą św. w kościele akademickim KUL pod przewodnictwem bpa ordynariusza kieleckiego Jana Piotrowskiego. Okolicznościowe kazanie wygłosił bp dr hab. Mariusz Leszczyński, biskup pomocniczy zamojsko-lubaczowski. W mowie przypomniał swoje kontakty naukowe z ks. prof. B. Kumorem podczas studiów historycznych na KUL. Zwrócił również uwagę na działalność duszpasterską ks. Kumora, nie tylko w środowisku akademickim, ale również podczas wyjazdów naukowych. Na koniec bp M. Leszczyński ukazał osobę ks. prof. B. Kumora jako wzór dla wszystkich kapłanów-naukowców.

Dalsza część sesji miała miejsce w Czytelni Teologiczno-Filozoficznej Biblioteki Uniwersyteckiej KUL. Otwarcia sympozjum dokonali: dyrektor BU KUL mgr Barbara Zezula oraz dyrektor Ośrodka Archiwów Bibliotek i Muzeów Kościelnych KUL ks. dr. hab. prof. KUL Waldemar W. Żurek SDB. W swoim krótkim przemówieniu dyrektor B. Zezula, przypomniała związki ks. B. Kumora z Biblioteką Uniwersytecką KUL. Książnica posiada wszystkie publikacje ks. B. Kumora oraz przechowuje o nim pamięć poprzez okolicznościowe wystawy i informacje umieszczone na stronie internetowej.

Ks. W. Żurek otwierając sesję przypomniał pokrótce życie ks. B. Kumora (Sylwetka Księdza Profesora Bolestawa Kumora), który urodził się w Szymanowicach-Niskowej koło Nowego Sącza 1 grudnia 1925 r. w rodzinie chłopskiej. W rodzinnej miejscowości ukończył czteroklasową szkołę powszechną (19311937). Dwa dalsze lata uczył się w szkole powszechnej w Nowym Sączu. Po wybuchu II wojny światowej i likwidacji szkoły przez Niemców, przez dwa lata uczył się w Szkole Handlowej. W latach 1945-1947 uczęszczał do gimnazjum. W 1947 r. po uzyskaniu egzaminu dojrzałości wstąpił do Seminarium Duchownego w Tarnowie. W 1952 roku uzyskał magisterium z historii Kościoła na Uni- 
wersytecie Jagiellońskim w Krakowie oraz przyjął święcenia kapłańskie. Dalsze studia teologiczne (magisterium 1954, doktorat 1954 z historii Kościoła) i historyczne (magisterium 1957) odbył już na KUL. Habilitował się w roku 1959 i od początku 1960 r. zaczął pracować na KUL jako sekretarz naukowy Ośrodka Archiwów Bibliotek i Muzeów Kościelnych i wykładowca historii Kościoła. Był kierownikiem Katedry Historii Kościoła w Starożytności, a potem Katedry Historii Kościoła w Czasach Nowożytnych. Kierował Instytutem Historii Kościoła, a także był prodziekanem Wydziału Teologii. Ks. B. Kumor został profesorem nadzwyczajnym w $1970 \mathrm{r}$., zaś zwyczajnym w $1978 \mathrm{r}$.

Ks. B. Kumor był członkiem redakcji czasopism naukowych m.in. „Archiwa Biblioteki i Muzea Kościelne”, „Roczniki Teologiczno-Kanoniczne”, „Nasza Przeszłość”. Dorobek naukowy ks. prof. Bolesława Kumora obejmuje około 700 pozycji, w tym 37 książek. Najbardziej znane publikacje to: Historia Kościoła (8 tomów); Historia Kościoła w Polsce, razem z ks. Zdzisławem Obertyńskim (2 tomy); Granice metropolii i diecezji polskich 968-1939, Diecezja tarnowska. Dzieje ustroju i organizacji 1786-1985; Dzieje diecezji krakowskiej do roku 1795.

Władze kościelne uhonorowały ks. B. Kumora w 1982 r. godnością szambelana papieskiego, a w 1994 r., tytułem honorowego prałata papieskiego.

Następny referat: Tematyka ślaska w piśmiennictwie Księdza Profesora Bolestawa Kumora, wygłosił ordynariusz diecezji gliwickiej, bp prof. Jan Kopiec. W swojej mowie przypomniał osobiste kontakty naukowe z ks. prof. B. Kumorem, na którego wykłady uczęszczał jako student historii Kościoła KUL. Wprawdzie doktorat napisał na seminarium ks. prof. S. Librowskiego (Historiografia diecezji wrocławskiej do roku 1821), jednak często korzystał z dodatkowych wskazówek bibliograficznych ks. B. Kumora. Bp J. Kopiec w swoim wystappieniu wskazał na różnorodność publikacji ks. Kumora, która w odniesieniu do Śląska, była jednak bardzo skromna. Uczony ten miał jednak żywy kontakt ze śląskim środowiskiem naukowym, nie tylko kościelnym. Często przyjeżdżał na konferencje naukowe i z wykładami akademickimi do różnych instytucji naukowych Śląska. Bp J. Kopiec zwrócił również uwagę, że ks. B. Kumor podczas swoich pobytów naukowych na Śląsku, zawsze starał się pomagać w duszpasterstwie.

Kolejnym mówcą był bp dr Jan Piotrowski, ordynariusz diecezji kieleckiej, który przedstawił referat Ksiadz Profesor Bolesław Kumor we wspomnieniach kapłanów i biskupów. W wystąpieniu przypomniał czas swoich studiów w Seminarium Duchownym w Tarnowie, gdzie wykładowcą był ks. B. Kumor. Przywołał prowadzone przez niego zajęcia oraz wymienił niektóre prace naukowe alumnów tarnowskiego seminarium, których ks. Kumor był promotorem. Bp J. Piotrowski przypomniał również opinie kapłanów diecezji tarnowskiej o ks. B. Kumorze. Zwrócił szczególnie uwagę na osobę ks. Stanisława Pieprznika - przyjaciela ks. B. Kumora i proboszcza jego rodzinnej parafii Trzetrzewina. Bp J. Piotrowski przypomniał także działalność ks. Kumora na rzecz swojej parafii i miejscowości. W kościele parafialnym w Trzetrzewinie ufundował witraże, a w rodzinnej Niskowej wybudował klasztor z kaplicą pw. Narodzenia NMP i przekazał go siostrom zmartwychwstankom. Po śmierci ks. B. Kumora, siostry urządziły izbę pamięci z wyposażeniem pokoju w którym pracował. Ks. Kumor był również głównym 
fundatorem kościoła pw. św. Stanisława Kostki w rodzinnej wsi Niskowa. Jak wspominali księża i mieszkańcy, każdorazowy pobyt w rodzinnych stronach ks. B. Kumor wypełniał nie tylko pracą naukową, ale także posługą duszpasterską: odprawiał msze św., przewodniczył pogrzebom, błogosławił małżeństwa i spowiadał. Mawiano nawet: „Jeśli nie ma Go w konfesjonale, to nie ma Go wcale”. Zgodnie z Jego ostatnią wolą został pochowany przy kościele w rodzinnej Niskowej. Na płycie nagrobnej wyryto słowa Jana Pawła II o Zmarłym: Prawdziwie umitowat madrość, nieustannie jej poszukiwat....

Ks. prof. Anzelm Weiss wygłosił tekst wspomnieniowy Lata mojej wspótpracy z Księdzem Profesorem Bolestawem Kumorem. Ks. A. Weis był uczniem ks. Kumora i pod jego kierunkiem napisał pracę magisterską oraz rozprawę doktorską. Był również jego asystentem naukowym. Ks. A. Weiss wspominał porządkowanie po śmierci ks. B. Kumora jego mieszkania w konwikcie. Szczególnie zwrócił uwagę na skromne biurko profesora, które było symbolem jego pracy naukowej i najpełniej wyrażało jego życie. Ks. A. Weiss przypomniał również, że przyjście młodego ks. Kumora do pracy na KUL nie było łatwe, ponieważ tak zdolnego naukowca chciała mieć każda uczelnia. Kardynał Stefan Wyszyński osobiście interweniował u biskupa tarnowskiego Jana Stepy, w sprawie zatrudnienia na KUL ks. B. Kumora. W celu wyjaśnienia wspomnianych okoliczności ks. A. Weiss odczytał list bpa J. Stepy do kard. S. Wyszyńskiego z 23 kwietnia 1959 r.

$\mathrm{Na}$ koniec ks. A. Weiss, podsumowując życie ks. B. Kumora zauważył, że oprócz nauki, umiłował on szczególnie posługę w konfesjonale i dyskretnie świadczoną caritas dla potrzebujących. Znamiennym był fakt, że po śmierci ks. Kumora, studenci KUL umieścili wielki bukiet białych róż i dużą świecę w konfesjonale kościoła akademickiego, gdzie stale spowiadał.

Kolejnym prelegentem był ks. dr Andrzej Kwaśniewski, który przedstawił referat Podręczniki do historii Kościoła autorstwa Księdza Profesora Bolestawa Kumora. Wspomniana Historia Kościoła w ośmiu tomach ukazała się w dwóch wydaniach (1973-1979, 2001-2004) nakładem Wydawnictwa KUL. Służy ona w Wyższych Seminariach Duchownych oraz Wydziałach Teologicznych jako podstawowy podręcznik wykładowy. Tytuły poszczególnych tomów: I - Starożytność chrześcijańska, II - Wczesne średniowiecze chrześcijańskie, III - Ztoty okres średniowiecza chrześcijańskiego, IV - Jesień kościelnego średniowiecza, V Czasy nowożytne. Rozłam w chrześcijaństwie zachodnim, VI - Czasy nowożytne. Kościót w okresie absolutyzmu i oświecenia, VII - Czasy najnowsze 1815-1914, VIII - Czasy wspótczesne 1914-1992. Ks. B. Kumor opisywał historię Kościoła jako „dzieje ludu Bożego”, na tle dziejów całego chrześcijaństwa i świata. Autor podkreślał rolę Kościoła w rozwoju kultury i jego działalność misyjną w świecie.

Ks. A. Kwaśniewski wspomniał również o dziele ks. B. Kumora Historia Diecezji Krakowskiej. Pracę nad ostatnim, piątym tomem, dzieła przerwała śmierć autora. Według opinii ks. prof. Jacka Urbana:

Nawet zespół historyków nie jest w stanie dokończyć monografii Księdza Profesora Kumora o archidiecezji krakowskiej. Nikt nie posiada takiej wiedzy i nie dysponuje takimi możliwościami badawczymi. żeby w takim stylu, jak zostały napisane pierwsze cztery tomy, dopisać piąty. Mógł to zrobić tylko ksiądz Kumor. 
Kolejny referat Duchowieństwo diecezji tarnowskiej w latach 1945-1970. Struktura personalna, wygłosił ks. dr hab. Kazimierz Talarek. Na kanwie wprowadzanego w Polsce przez powojenne władze ustroju komunistycznej, przedstawił sytuację tarnowskiego Kościoła. W czasie największych prześladowań stalinowskich, wielu księży tarnowskich było szykanowanych, prześladowanych, więzionych oraz skazywanych na karę śmierci m.in. za działalność w czasie okupacji niemieckiej w AK czy też pomoc Żołnierzom Wyklętym. Na tle sytuacji duchowieństwa tarnowskiego, prelegent przedstawił losy ks. B. Kumora, który tak jak wszyscy księża był inwigilowany i prześladowany. Ze względu na jego nieugiętą postawę wobec komunistycznych władz oraz pracę duszpasterską wśród młodzieży, ks. B. Kumor był ciągle szykanowany. Służby bezpieczeństwa PRL śledziły go i wzywały na przesłuchania, a nawet opieczętowały mu mieszkanie. Trzykrotnie władze państwowe domagały się pozbawienia ks. Kumora pracy w szkolnictwie wyższym. Przez wiele lat Ministerstwo Nauki nie zatwierdziło mu habilitacji, a przez ponad 10 lat nie wydawano mu paszportu. Pomimo tych trudów ks. B. Kumor nigdy nie zmienił swojej krytycznej oceny władz państwowych i rzeczywistości PRL oraz nie zaniechał dotychczasowej działalności naukowo-duszpasterskiej.

Kolejnym prelegentem był mgr Krzysztof Perzyna, który przedstawił referat Prace naukowe napisane pod kierunkiem Księdza Profesora Bolesława Kumora. W swoim wystąpieniu przypomniał, że ks. Kumor prowadził seminaria naukowe nie tylko w KUL, ale i Papieskiej Akademii Teologicznej w Krakowie oraz w Wyższym Seminarium Duchownym w Tarnowie. Pod jego kierunkiem powstało ponad 350 prac magisterskich i 40 rozpraw doktorskich. K. Perzyna przypomniał słuchaczom, że ks. B. Kumor ufundował nagrodę swego imienia za najlepsze prace dyplomowe powstałe w Instytucie Historii Kościoła KUL oraz na PAT (Uniwersytet Papieski Jana Pawła II) w Krakowie.

Ostatni referat wygłosił dr Artur Hamryszczak, Publikacje naukowe Księdza Profesora Bolestawa Kumora na tamach pótrocznika Archiwa, Biblioteki i Muzea Kościelne. Przypomniał w nim, że ks. Bolesław Kumor, był członkiem redakcji półrocznika „Archiwa Biblioteki i Muzea Kościelne”, a następnie członkiem Rady Naukowej pisma, sekretarzem Ośrodka Archiwów Bibliotek i Muzeów Kościelnych i jego dyrektorem. Z tego też względu na łamach półrocznika ABMK opublikował sprawozdania $z$ działalności Ośrodka ABMK oraz kursów zawodowych organizowanych dla pracowników kościelnych archiwów, bibliotek i muzeów. Ks. Kumor drukował również katalogi mikrofilmów Ośrodka ABMK. Największą grupą piśmiennictwa jego autorstwa stanowiły wydawnictwa źródłowe (erekcje, fundacje, relacje biskupie, statuty, kopiarze) oraz wieloczęściowe publikacje dotyczące demografii i granic Kościoła katolickiego w Polsce.

Sesję naukową zakończył dyrektor Ośrodka ABMK ks. dr hab. prof. KUL Waldemar W. Żurek, podsumowując obrady i informując, że materiały pokonferencyjne ukażą się drukiem. 